\title{
PENGARUH PEMBERIAN INFUSED WATER LEMON (Citrus Limon) DAN JAHE MERAH (Zingiber Officinale Varietas Rubrum) UNTUK MENURUNKAN MUAL- MUNTAH PADA IBU HAMIL TRIMESTER I DI KLINIK PRATAMA MARIANA MEDAN TAHUN 2020
}

\author{
Fitri Yana Kaban ${ }^{1}$, Bella Vetriyasa ${ }^{2}$, Desy Khairani ${ }^{3}$, Chrismis Novalinda Ginting ${ }^{4}$
} Universitas Prima Indonesia, Indonesia

\section{Article Info}

\section{Article history:}

Received Nov 09, 2020

Revised Mar 08, 2021

Accepted Mar 15, 2021

\section{Keywords:}

Lemon Infused Water Nausea and Vomiting Pregnant Women

\begin{abstract}
Pregnancy causes physical, psychological and hormonal changes in the body of a pregnant woman. This causes various complaints experienced by the mother, one of which is nausea and vomiting or often called morning sickness which usually occurs early in pregnancy (first trimester). Nausea and vomiting experienced by pregnant women are due to increased levels of the hormones estrogen and progesterone produced by Human Chorionic Gonadotropine (HCG) in serum from the placenta. Morning sicknes occur not only in the morning but can occur at any time of the day and even at night. General objective, to determine the effect of giving lemon and red ginger infused water to reduce nausea and vomiting in first trimester pregnant women at the Mariana Primary Clinic in Medan in 2020. The study was conducted in July 2020, the population in this study were pregnant women who experienced nausea and vomiting. in the first trimester of pregnancy at the Primary Mariana clinic in Medan in 2020 as many as 25 people. The sample in this study was taken using purposive sampling technique. The inclusion criteria were pregnant women who were not fasting, liked ginger and lemon to be able to consume infused water, and were not taking drugs. While the exclusion criteria were pregnant women who took drugs and pregnant women who did not like ginger and lemon. Then the number of samples in this study were 18 people. Quasi-experimental design (quasy experiment), namely the one group pretest and post-test approaches. Wilcoxon Signed Rank Testpre and post test results obtained from the $\mathrm{Z}$ value of 3.397 with a $p$-value of 0.001 . From the test value $p$-value 0.001 $<0.005$ (H0 rejected). This shows that there is a difference between before giving Lemon Infused Water and after being given Lemon Infused Water. Based on these results, it can be concluded that there is an effect of giving lemon infused water (citrus limon) and red ginger (zingiber officinale rubrum variety) to reduce nausea and vomiting in trimester I pregnant women.
\end{abstract}

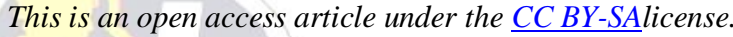

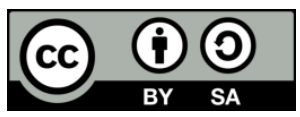

Corresponding Author:

Fitri Yana Kaban,

S1 Kebidanan,

Universitas Prima Indonesia,

Jl. Danau Singkarak, Gg. Madrasah SeiAgul, Kec.Medan Barat, Kota Medan - Sumatera Utara.

Email: fitriyanakaban1995@gmail.com 


\section{INTRODUCTION}

Menurut (Ayu Dwi Putri, 2017) Kehamilan dapat menyebabkan perubahan fisik, psikis dan hormonal pada tubuh ibu hamil hal ini menimbulkan berbagai keluhan yang dialami ibu salah satunya mual dan muntah atau sering disebut Morning sickness yang biasa terjadi diawal kehamilan (trimester I). Mualmuntah yang dialami ibu hamil dikarenakan adanya peningkatan kadar hormon estrogen dan progesterone yang diproduksi oleh Human Chorionic Gonadotropine (HCG) dalam serum dari plasenta. Morning sicknes terjadi tidak hanya di pagi hari melainkan bisa terjadi setiap saat siang bahkan malam hari. Selain itu indra penciuman yang dialami ibu hamil juga meningkat apabila mencium aroma bau-bauan contohnya bau masakan, parfum dan sebagainya, setengah dari ibu hamil akan mengalami mual dan muntah apabila merasakan bau tersebut. Mual dan muntah apabila terjadi berlebihan juga memiliki dampak pada janin yang dikandung ibu misalnya abortus, bayi lahir rendah dan kelahiran tidak cukup bulan (prematur), pertumbuhan janin terhambat (Intrauterine Growth Retardation/IUGR) juga akan meningkat pada ibu hamil dengan hiperemesis gravidarum. Cara meredakan mual dan muntah juga dapat dilakukan melalui tindakan farmakologi dan non farmakologi. Berikut beberapa Tindakan non farmakologi yang sering dianjurkan oleh tenaga medis seperti tehnik relaksasi, pemberian teh/wedang jahe, aromaterapi.

Nausea Gravidarum (NVP), atau disebut Morning sickness bahwa dari hasil yang didapat bahwa hampir 50\%-90\% ibu hamil akan merasakan mual dan muntah pada kehamilan 3 bulan pertama kehamilan (trimester I). Keadaan ini akan membaik ketika usia kehamilan memasuki 12-16 minggu kehamilan (trimester kedua). Keadaan ini terjadi sekitar 60\%-80\% primigravida dan pada multigravida terjadi sekitar 40\%-60\%. Keluhan mual-muntah yang dialami ibu hamil merupakan hal yang bersifat fisiologis, akan tetapi apabila keluhan tersebut tidak segera diatasi, maka akan menjadi hal yang patologis sehingga menyebabkan gangguan pada kehamilan ibu. Riset yang telah dilakukan oleh Vutyavanich dari Universitas Chiang Mai di Thailand tentang khasiat jahe untuk meredakan mual-muntah yang dialami oleh ibu hamil (Ummi dan Mahmudah, 2014).

Jahe terbukti memiliki aktivitas antiemetik (anti muntah) yang manjur, jahe sangat efektif untuk mengatasi mual dan muntah pada Ibu Hamil Trimester I. Selain jahe, buah lemon juga dapat digunakan untuk mengatasi mual dan muntah, selain dalam bentuk sediaan aromatherapy, di dalam buah lemon terdapat vitamin $\mathrm{C}$ dan minyak Atsiri. Infused water adalah potongan dari beberapa buah-buahan yang akan dicampur dengan air yang sudah matang lalu didiamkan beberapa saat di dalam lemari es (6-12 jam) untuk dapat mengeluarkan sarinya. Kandungan infused water dapat memberikan energi ekstra bagi ibu hamil. Tiga unsur gizi penting seperti air, mineral dan vitamin dapat mengatasi ibu hamil yang mengalami dehidrasi selama mual dan muntah pada ibu hamil (Anis Novitasari).

Berdasarkan data WHO hiperemesis gravidarum terjadi di seluruh dunia diantaranya benua Amerika 0,5-2\%, sebenyak 0,3\% di Swedia, 0,5\% di California, 0,8\% di Canada, 10,8\% di China 0,9\% di Nowergia, 2,2\% di Pakistan dan 1,9\% di Turki sedangkan di Indonesia angka kejadian Hiperemesis gravidarum di Indonesia adalah mulai 1-3\% dari seluruh kehamilan (Evi susanti, 2019).

Berbagai penelitian pemberian infused water jahe dan lemon telah dilakukan diantaranya penelitian yang dilakukan oleh Anis Novitasari tentang pengaruh jahe dan lemon untuk menurunkan mual-muntah pada yang dilakukan pada 17 ibu hamil yang mengalami mual-muntah sedang-berat dan setelah mengonsumsi infused water tersebut 16 ibu hamil termasuk kategori ringan dengan nilai $\mathrm{p}$ value 0,0001 yang dilakukan di Klinik Pratama Nur Hikmah Kabupaten Grobogan.

Berdasarkan dari hasil uraian-uraian diatas baik dalam hasil peneliti sebelumnya maka peneliti tertarik untuk melakukan penelitian mengenai infused water tersebut dan berdasarkan survey awal yang telah dilakukan peneliti di klinik pratama mariana. Peneliti mendapatkan jumlah Ibu Hamil Trimester I sebanyak 25 orang dimana sebanyak 18 orang ibu hamil tersebut mengalami mual muntah dengan kategori beratsedang.

\section{RESEARCH METHOD}

Jenis penelitian ini menggunakan penelitian kuantitatif dengan rancangan eksperimen semu (quasy ekspriment) yaitu dengan pendekatan one group pretest dan post-test dimana desain ini untuk mengetahui perubahan yang terjadi sebelum diberikan tindakan dan setelah dilakukannya tindakan pada kelompok kontrol dan kelompok eksprimen kemudian diobservasi setelah dilakukan intervensi.

Lokasi penelitian akan dilakukan di Klinik Pratama Mariana Medan Tahun 2020. Dengan alasan sebagai berikut: Sampel yang dibutuhkan memenuhi syarat untuk dilakukan penelitian. Klinik Mariana memberikan izin untuk dapat melakukan penelitian tersebut. Penelitian ini direncanakan dilakukan pada bulan Juli 2020. Populasi adalah keseluruhan objek penelitian atau objek yang diteliti (Notoadmodjo, 2010). Populasi dalam penelitian ini adalah ibu hamil yang mengalami mual-muntah pada kehamilan trimester I di klinik Pratama Mariana Medan Tahun 2020 sebanyak 25 Orang. Sampel adalah objek yang diteliti dan dianggap dapat mewakili seluruh pupulasi (Notoadmodjo, 2010). Sampel dalam penelitian ini diambil 
menggunakan teknik Purposive Sampling yaitu pengambilan sampel secara Purposive Sampling didasarkan pada suatu pertimbangan tertentu yang dibuat oleh peneliti sendiri berdasarkan inklusi dan eksklusi. Kriteria inklusi dalam penelitian ini yaitu ibu hamil yang tidak sedang berpuasa, menyukai jahe dan lemon untuk dapat mengonsumsi Infused Water, serta tidak sedang mengonsumsi obat. Sedangkan eksklusi pada penelitian ini adalah yaitu ibu hamil yang mengonsumsi obat dan ibu hamil yang tidak menyukai jahe dan lemon. Maka jumlah sampel dalam penelitian ini sebanyak 18 Orang.

Cara Pembuatan Infused Water: Siapkan buah lemon dan jahe yang telah dicuci bersih, potong buah lemon dan jahe menjadi beberapa bagian masukkan potongan buah kedalam termos yang berisi air matang lalu diamkan dalam lemari es selama 1-4 jam sebelum disajikan untuk mengeluarkan sarinya infused Water siap dikonsumsi ibu hamil. Infused Water ini sangat bermanfaat karena cairan Infused Water mengandung 3 unsur gizi yang penting yaitu air, vitamin dan mineral yang dapat mencegah ibu mengalami dehidrasi selama masa kehamilan. Penelitian ini merupakan penelitian quasy ekspriment karena penelitian ini ingin mengidentifikasi menggunkan lembar observasi ada tidaknya pengaruh variabel dependen terhadap variabel independen. Tujuan lembar obsevasi tersebut untuk membantu peneliti menilai dan menemukan kesimpulan dari solusi yang dibutuhkan. Lembar observasi dalam penelitian ini digunakan untuk mencatat hasil observasi pada responden yang diukur sebelum dan sesudah dilakukan pemberian Infused Water pada ibu hamil.

Analisis bivariat dilakukan untuk mengetahui variabel independen secara menyeluruh dan melihat persentasi variabel tersebut. Data variabel ini adalah numerik dengan satu kelompok berpasangan (satu kelompok intervensi) dan menggunakan uji statistik non-parametrik yaitu uji wilcoxon karena menggunakan skala ordinal. Uji statistik dengan menggunakan taraf signifikansi 5\%, maka kriteria pengujian adalah jika signifikansi $>0,05$ maka $\mathrm{H}_{0}$ diterima dan jika signifikansi $<0,05$ maka $\mathrm{H}_{0}$ ditolak. Tahap pengujian hipotesis menggunakan SPSS dengan uji wilcoxon.

\section{RESULTS AND ANALYSIS}

\subsection{Hasil}

\section{Analisa Univariat}

Berdasarkan hasil penelitian yang dilakukan pada bulan Juli tentang Pengaruh Pemberian Infused Water Lemon (Citrus Limon) dan Jahe Merah (Zingiber Officinale Varietas Rubrum) untuk menurunkan mual-muntah pada Ibu Hamil Trimester I di Klinik Pratama Mariana Tahun 2020 maka diperoleh hasil sebagai berikut:

Tabel 1. Karakteristik Distribusi Frekuensi Responden Berdasarkan Usia, Paritas Dan Usia Kehamilan

\begin{tabular}{ccc}
\hline Usia & Jumlah & Persentase (\%) \\
\hline $22-29$ tahun & 12 & 66,7 \\
\hline $30-39$ tahun & 6 & 33,3 \\
\hline Total & 18 & 100 \\
\hline \multicolumn{3}{c}{ Paritas } \\
\hline Primigravida & 11 & 61,1 \\
\hline Multigravida & 7 & 38,9 \\
\hline 7 minggu & Usia Kehamilan \\
\hline 8 minggu & 2 & 11,1 \\
\hline 9 minggu & 3 & 16,7 \\
\hline 10 minggu & 3 & 16,7 \\
\hline 11 minggu & 3 & 11,1 \\
\hline 12 minggu & 4 & 16,7 \\
\hline 13 minggu & 1 & 22,2 \\
\hline
\end{tabular}

Berdasarkan tabel 1, diperoleh data karakteristik tertinggi Ibu Hamil Trimester I terjadi pada usia 22-29 tahun sebanyak 12 orang $(61,7 \%)$, primigravida mayoritas 11 orang $(66,7 \%)$ dan usia kehamilan rata rata yang lebih banyak 12 minggu $(22,2 \%)$.

\section{Analisa Bivariat} berikut :

Berdasarkan hasil penelitian dengan menggunakan Analisa Bivariat, maka diperoleh hasil sebagai

Tabel 2. Distribusi Frekuensi Responden Sebelum (Pre-Test) Perlakuan

\begin{tabular}{ccc}
\hline Karakteristik & Frekuensi & Persentase $(\%)$ \\
\hline $4-6$ (Sedang) & 6 & 33,3 \\
\hline $7-10$ (Berat) & 12 & 66,7 \\
\hline Total & 18 & 100 \\
\hline
\end{tabular}


Berdasarkan hasil penelitian pada tabel 2, sebelum diberikan Infused Water Lemon dan Jahe Merah pada Ibu Hamil Trimester I diperoleh hasil yang mengalami mual-muntah antara 4-6 kali (sedang) sebanyak 6 responden dan yang mengalami mual-muntah atau 7-10 kali (berat) sebanyak 12 responden.

Tabel 3. Distribusi Frekuensi Responden Sesudah (Post-Test) Perlakuan

\begin{tabular}{ccc}
\hline Karakteristik & Frekuensi & Persentase $(\%)$ \\
\hline 1-3 ringan & 12 & 66,7 \\
\hline 4-6 sedang & 2 & 11,1 \\
\hline 7-10 berat & 4 & 22,2 \\
\hline Total & 18 & 100
\end{tabular}

Berdasarkan hasil penelitian pada tabel 3, sesudah diberikan perlakuan pemberian Infused Water Lemon dan Jahe Merah pada Ibu Hamil Trimester I didapat hasil bahwa terdapat penurunan mual-muntah 1-3 kali (ringan) sebanyak 12 orang responden. Sedangkan yang tidak mengalami perubahan ada sebanyak 4 orang dengan nilai 7-10 kali (berat).

Tabel 4. Hasil Uji Wilcoxon Signed Rank Test Sebelum Dan Sesudah Perlakuan

\begin{tabular}{ccccccc}
\hline Variabel & $\mathbf{N}$ & Mean & Std. Deviation & $\mathbf{Z}$ & $\mathbf{P}-$ Value & Kesimpulan \\
\hline Pre - test & 18 & 2,67 & 0,485 & $-3,397^{\mathrm{b}}$ & 0,001 & $\mathrm{H}_{0}$ ditolak \\
\hline Post - test & 18 & 1,56 & 0,856 & $-3,397^{\mathrm{b}}$ & 0,001 & $\mathrm{H}_{0}$ ditolak \\
\hline
\end{tabular}

Berdasarkan hasil penelitian pada tabel 4, dapat dilihat bahwa dari uji Wilcoxon Signed Rank Test pre dan post diperoleh hasil dari nilai $\mathrm{Z}$ sebesar 3,397 dengan nilai p-value sebesar 0,001. Dari nilai uji $p$ value $0,001<0,005$. Sehingga disimpulkan bahwa $\mathrm{H}_{0}$ ditolak, artinya terdapat perbedaaan antara sebelum dilakukan pemberian Infused Water Lemon dan sesudah diberikan Infused Water Lemon.

\subsection{Pembahasan}

Bedasarkan hasil penelitian yang dilakukan pada Klinik Pratama Mariana Medan, dimana responden perempuan sebanyak 18 orang. Usia Ibu Hamil Trimester I rentang usia 22-29 sebanyak 12 orang. Sedangkan usia 30-39 berjumlah 6 orang. Berdasarkan tabel 2 sebelum dilakuan pemberian Infused Water Lemon dan Jahe Merah untuk penurunan mual dan muntah Ibu Hamil Trimester I sebanyak 12 responden mengalami mual-muntah antara 7-10 kali (berat). Berdasarkan tabel 3, setelah diberikan infused water lemon dan Jahe Merah untuk menurunkan mual dan muntah pada Ibu Hamil Trimester I terdapat perubahan sebanyak 12 responden yang mengalami mual-muntah 1-3 kali (ringan). Berdasarkan hasil dari uji Wilcoxon Sign Rank Test didapat nilai $\mathrm{Z}$ sebesar 3,397 dan p-value 0,001 sehingga dapat disimpulkan $\mathrm{H}_{0}$ ditolak dan $\mathrm{H}_{\mathrm{a}}$ diterima, artinya terdapat pengaruh pemberian Infused Water Lemon dan Jahe Merah untuk menurunkan mual dan muntah pada Ibu Hamil Trimester I.

Jahe Merah merupakan tanaman yang memiliki sejuta khasiat yang telah dikenal sejak lama. Jahe Merah merupakan salah satu jenis rempah penting yang memiliki efek menyegarkan dan dapat menekan mual-muntah. Lemon juga merupakan salah satu herbal yang digunakan selama kehamilan yang dapat mengurangi mual-muntah pada ibu hamil. Kandungan yang terdapat pada buah lemon dapat mengurangi mual-muntah dan mengurangi rasa nyeri.

Hasil penelitian yang dilakukan oleh Anis Novitasari tentang pengaruh Jahe Merah lemon untuk menurunkan mual-muntah pada 17 ibu hamil yang mengalami mual-muntah sedang, berat dan setelah mengonsumsi Infused Water terdapat perubahan dengan nilai p-value 0,0001. Infused Water adalah potongan dari beberapa buah-buahan yang dicampur dengan air matang lalu didiamkan beberapa saat didalam lemari es selama 6-12 jam untuk dapat mengeluarkan sarinya. Mual-muntah yang dialami ibu hamil disebabkan oleh peningkatan kadar hormon estrogen dan progesteron yang diproduksi dari Human Chorionic Gonadotropine (HCG) dalam serum dalam plasenta. Apabila terjadi secara berlebihan akan memiliki dampak pada janin yang dikandung ibu misalnya abortus, bayi lahir rendah dan kelahiran tidak cukup bulan (premature). Menurut asumsi peneliti mual-muntah yang terjadi pada Ibu Hamil Trimester I dapat diatasi dengan pemberian Infused Water Lemon dan Jahe Merah.

\section{CONCLUSION}

Berdasarkan uji Wilcoxon Signed Rank Testpre dan post, diperoleh nilai Z sebesar 3,397 dengan nilai $p$-value sebesar 0,001 . Nilai uji p-value 0,001<0,005 ( $\mathrm{H}_{0}$ ditolak). Hal ini menunjukkan bahwa terdapat perbedaaan antara sebelum dilakukan pemberian Infused Water Lemon dan sesudah diberikan Infused Water Lemon. Berdasarkan hasil uji tersebut maka dapat disimpulkan bahwa ada pengaruh pemberian Infused Water Lemon dan Jahe Merah untuk menurunkan mual-muntah Ibu Hamil Trimester I di Klinik Pratama Mariana Tahun 2020. 


\section{REFERENCES}

Ayu Dwi Putri. 2017. Asuhan Kehamilan Untuk Kebidanan. Jakarta: Salemba Medika.

Ummi dan Mahmudah. 2014. Pengaruh Pesalinan dan Kompliksi, edisi 3. Jakarta: EGC.

Anis Novitasari. 2017. Pengaruh Infused Water Lemon (Lemon dan Jahe Emprita) Terhdap Keluhan Mual Muntah Ibu Hamil Trimester I di Klinik Pratama Nur Hikmah Gubuk edisi Januari- Juni 2017.

Ummi Hasana, dkk. 2014. Efektivitas Pemberian Wedng Jahe Terhadap Penurunan emesis. ISSN 81-87. Vol. 3 No.1 2014.

Siti Rofi'ah ddk. 2019. Efektivits Aromaterapi Lemon Untuk Mengatasi emesis Garavidarum, Jurnal Kebidnnan I. ISSN 2089-7669.

Rahmi fitri. 2013. Efektifitas Jahe Untuk Menurunkan Mual Muntah pada Kehamilan Trimester I Jurnal Vol 1 No.2.

Notoatmodjo. 2010. Metodologi Penelitian Kesehatan. Jakarta: Rineka Cipta. 